\title{
INFLUENCE OF COMPOUND 16.842 ON HOOKWORM INFECTIONS
}

\author{
J. Rodrigues da Silva * and Léa Camillo-Coura **
}

\begin{abstract}
Compound 16.842 was tried with three d:fferent groups of patients in order to evaluate its tolerancy, and efficacy as well, with a view of using the drug in mass campaigns against hookworm.

Group I, used for a preliminary trial, consisted of 38 patients attending an out-patient clinic, and living either in the out-skirts or in the various urban areas of the city of $R_{.0}$ de Janeiro, including some inmates of an orphanage.

Group II, a field trial, was carried out in two farms, where the drug was administered both to the positive cases (124) and to the rest of the population (nearly $90 \%$ ).

Group III, a field trial was also carried out in a small town where nearly $40 \%$ of the total population was treated with the Compound.

Tolerability was considere 1 rather satisfactory, mainly among the patients receiving two single doses $(50-150 \mathrm{mg})$, according to the age, $4-6$ weeks apart). These results suggest that 2-4 courses of therapy within a shorter span of time should be the ideal for a mass treatment campaign.

Efficacy varied from $26.6 \%$ to $76.2 \%$ parasitoiog:cal cure in the various groups, with a wide range of variation also in the percent of mean reduction of eggs for hookworm.

The drug showed also some effect against Ascaris lumbricoides giving cure rates between $16,5 \%$ and $35.7 \%$ in the various groups, with a percentage reduction in mean egg counts of $27 \%$ to $83.3 \%$ according to the various groups.

It was concluded that Compound 16.842 possesses a marked effect on hookworm and a mild effect on A. lumbricoides. The findings in licate the need for more accurate stulies to determine the most efficient schedules of treatment and the real value of the drug, as compared to other antihelminthics against the two parasites under study.
\end{abstract}

Intestinal helminthiasis have been known to constitute a major Public Health problem in Brazil for many decades, if not for centuries. Amorig these helminthic diseases, (Figs. I-A and B), hookworm infection, for obvious reasons (high prevalence, wide distribution and unde: certain circumstances, a hign degree of morbity, in terms of impairment, disability and even death) has deserved special attention from the Public Health Service authorities, mainly at the Federal level.
Mass campaigns aiming at the control of hookworm infection were organized on three different occasions. At the present time, most of the activities concerning the control of intestinal helminthic infections are under the responsibility of the "Departamento Nacional de Endemias Rurais", an agency of the Ministery of Health. A branch of that department, the "Instituto Nacional de Endemias Rurais" is in charge of special investigation and research of the various endemic rural diseases. In ad-

- Full Professor of Tropical Medicine, Federal University of Rio de Janeiro Medical School; Director, National Institute of Endemic Rural Diseases, Ministery of Health, Rio de Janairo, Brazil.

* Assistant Professor of Tropical Medicine, Fede ral University of Rio de Janeiro Medical School, Brasil; D.C.M.1. (London). 
dition to wide scale surveys to determine the prevalence of these diseases, the value of the different diagnostic techniques is appraised. Regarding the intestinal helminthic diseases, pilot-projects for clinical trials of antihelminthic drugs are carried out as well as studies to evaluate the result of the control measures. Studies on other angles of the problem (practicability, cost, etc.) are also made.

Due to the high prevalence of associated intestinal helminthic infections found all over the country, control measures must always be selected and conducted with a view of attacking the greatest possible number of those endemic parasitic diseases not only through mass treatment, but also through environmental sanitation, health education, etc.

The main purpose of this paper is to present the observations made on the use of a new drug (Compound 16.842) which, according to previous experiences, has been found to be effective against hookworm infection in various parts of the world.

\section{MATERIAL AND METHODS}

Compound 16.842 is a colorless, tasteless and inodorous powder derived from the mustard oil; acute and chronic toxicity studies in animals failed to reveal significant physiopathological changes directly attributable to druy toxicity. Animal experiments showed that Compound 16.842 is specially effective against Ankylosioma and Ascaris, with relative efficacy against Cestodes.

The patients selected for the therapentical trials may be divided into three groups:

I-A and I-B) - Preliminary trials. 38 were patients ( 8 to 62 years of age) attending an out-patient clinic. Their residence was either in the suburbs or the various areas of the eity of Rio de Janeiro. Some of them were inmates from an orphanage.

II-A and B) - Field trials in rural areas. In two farms (Figs. II-A and B) of the municipality of Sumidouro (about 100 miles from the city of Rio de Janeiro) stool examination revealed 124 positive cases.
(44.2\% of the total population). In these two places several other helminthic diseases, including schistosomiasis mansoni are highly prevalent. Besides treatment for the positive cases, mass treatment was provided for the rest of the population. Ten positive cases, for different reasons, did not receive any course of treatment.

III - Field trials: (in a semi-rural community.) 298 patients were positive for hookworm at the first stool examination, representing $43 \%$ of the 693 people submitted to stool examinations; 134 of these patients received treatment. These people live in the sami-rural town of Sumidouro (about 1000 inhabitants), a locality which has some of its streets paved, a public swimming pool, and is partially served by a sewage system and water supply. (Fig. III).

Table I shows the data regarding age and sex for the three groups.

All of the patients in group I had the diagnosis established by the results of stool examinations, using the sedimentation method (Hoffman et all technique), (7) while all of those in group II and III were examined by the MIFC' $\$$ technique, a modification of the Sapero et al. technique, (Table II). In both groups, the stools of almost all patients were submitted to a counting method, Barbosa technique (1). The hookworm burden was low in the three groups. Nevertheless, it was higher in group I (Table III) .

The general health status of all patients was rather satisfactory although those of group I, II and part of group III, lived in a very unhealthy environment. 286 people of group II lived in 48 houses of which only 8 had tap water and 15 had latrines. Children and most of the adults go barefoot as a rule. Table IV shows the hematological findings as well as the results of serum protein and iron determination in 60 random positive patients of group II (farms.) The results of these studies reveal a mild hypochromic anemia in most of those patients as well as minor changes in the biochemical results.

In the town of sumidouro itself, most of the adults wear shoes while only a few children do so, at least as a habit. 


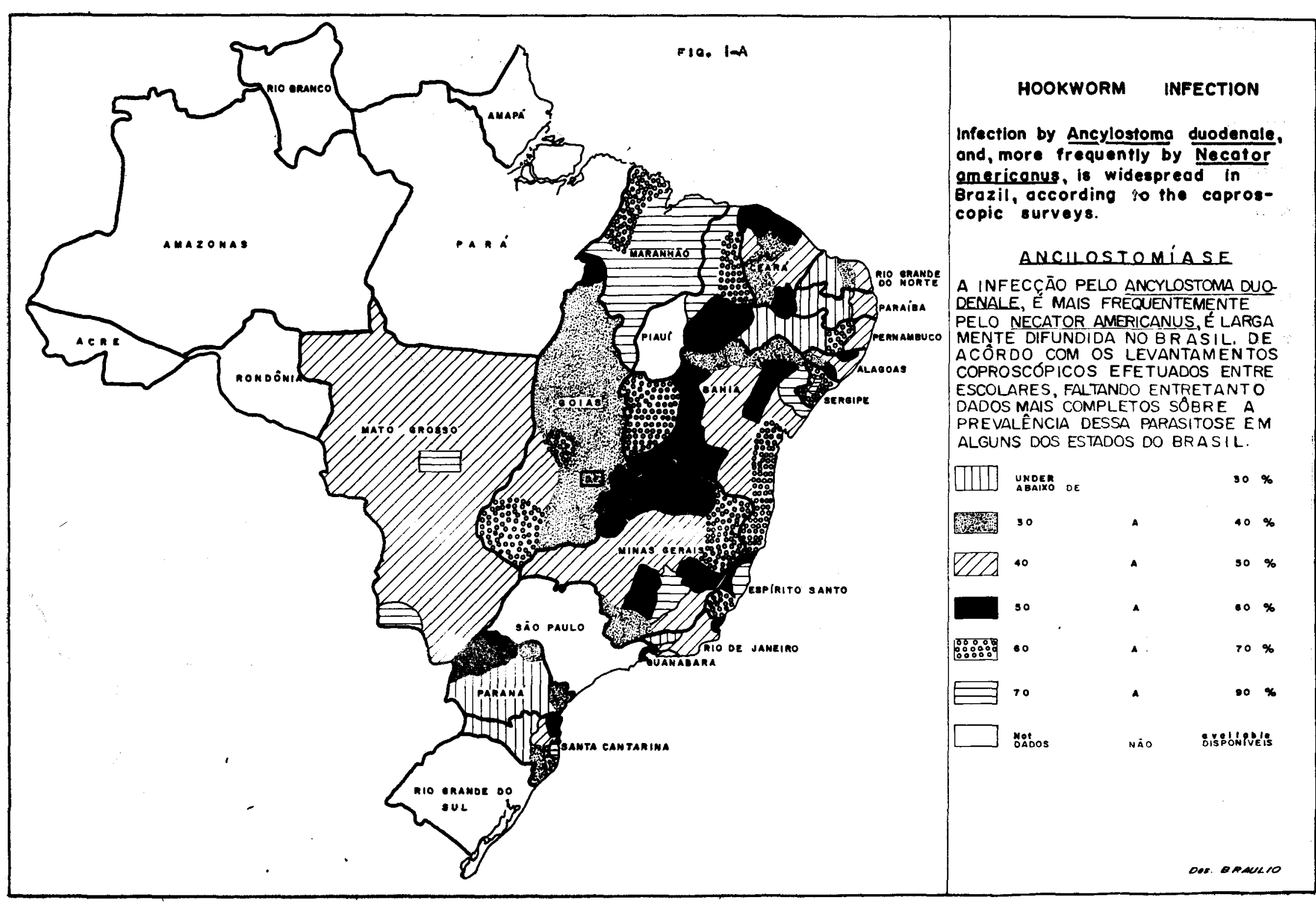




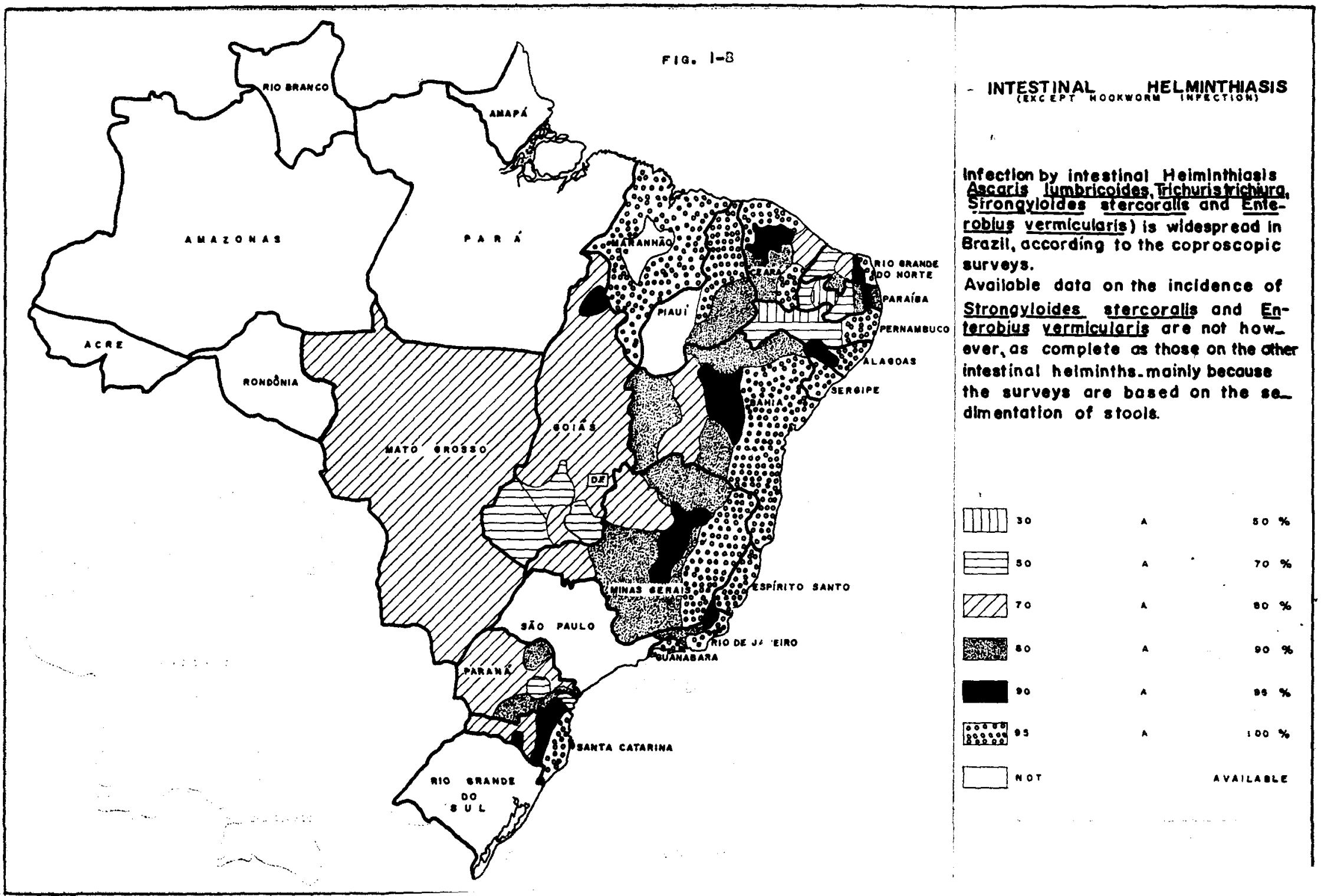




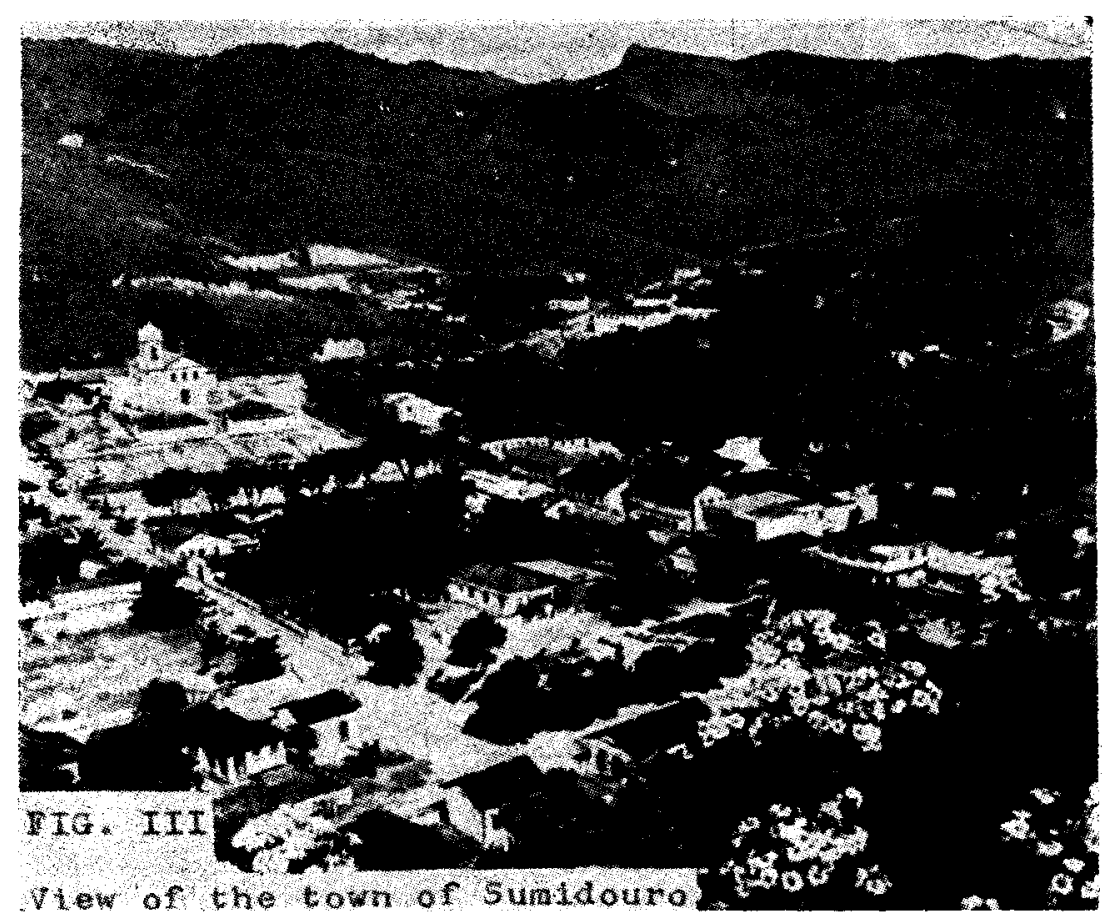

The treatment regimen used was as described in Table $v$.

To those of group I, the drug was given by a "sanitary" guard or an assistant nurse, while in the cases of groups II and III, it was always given by the medical doctor in charge of the study. In these two last groups, the Compound was administered to a large part of the population regardless whether the person was infected or not. As shown in Table VI, a few patients found negative before the treatment became positive after the first dose and even after the second course of therapy. The parents of the children and the adults themselves were properly instructed to communicate any untoward symptoms to the local Public Health Medical Doctor or to the Health Educator of the project. A record of all complaints of the patients was kept. Stool examinations were repeated by the same techniques already mentioned around the 30th day after the first course and again 30 days after the second cose.

\section{COOPERATION OF THE PATIENTS}

Cooperation was rather satisfactory in group I, while in group II, 10 refused the first treatment, 23 the second treatment and four refused both treatments. Besides that, 33 did not receive the Ist treatment due to pregnancy, difficulty of ingestion of the capsules, problems of age, change of residence etc. Because of the same reasons 27 did not receive the second treatment; and 29 did not receive both treatments, which means that 33 patients did not receive any treatment.

In group III, the cooperation of the population was even worse, as 339 refused to take the drug; 121 failed to take the drug for various other reasons. 233 received the first treatment and 151 the second; 147 people were given bch treatments.

\section{TCLERABILITY}

Table VII shows the side effects observed in the patients of the three groups. There were variations in the incidence and spectrum of side effects, according to the groups and the schedules as follows:

I) Side effects as a rule were more severe and more frequent after the first dose than after the second (group II).

2) Side effects were more intense and more frequent with a single dose schedule (200-300mg, according to the weight, 


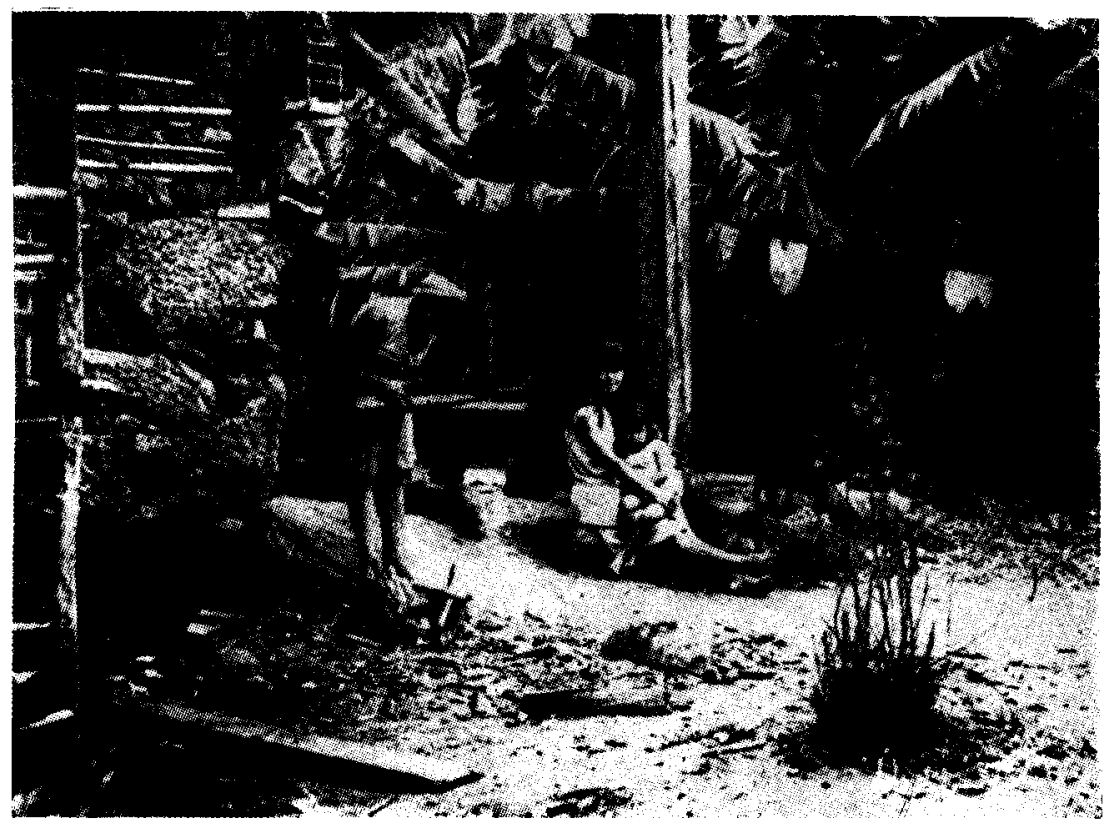

Fig. II $A$ : $A$ view of $\alpha$ dwelling on tarm $A$ (Boa Visia)

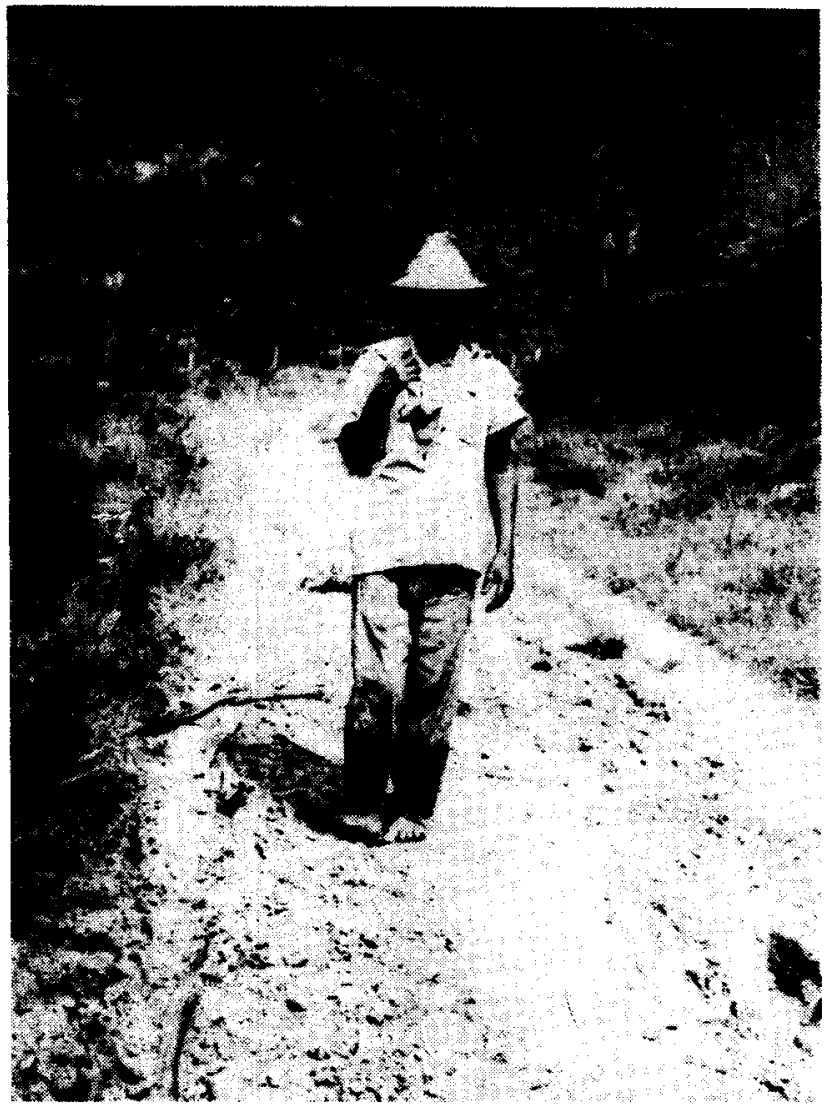

Fig. II B: Picture of a typical tarm dweller on farm B (Pamparão) 
TABLE I

DISTRIBUTION GF CASES ACCORDING TO AGE, SEX AND COLOUR

\begin{tabular}{|c|c|c|c|c|}
\hline & & GROUP I & GROUP II & GROUP III \\
\hline $\begin{array}{l}\text { AGE } \\
\text { (years) }\end{array}$ & $\begin{array}{l}2-6 \\
7=14 \\
>14\end{array}$ & $\begin{array}{l}13 \\
25\end{array}$ & $\begin{array}{l}19 \\
30 \\
75\end{array}$ & $\begin{array}{r}37 \\
95 \\
166\end{array}$ \\
\hline SEX & $\begin{array}{c}\text { MALE } \\
\text { FEMALE }\end{array}$ & $\begin{array}{l}11 \\
27\end{array}$ & $\begin{array}{l}72 \\
52\end{array}$ & $\begin{array}{l}157 \\
141\end{array}$ \\
\hline COLOUR & $\begin{array}{c}\text { WHITE } \\
\text { BLACK } \\
\text { MESTIZOES }\end{array}$ & $\frac{27}{11}$ & $\begin{array}{r}81 \\
34 \\
9\end{array}$ & $\begin{array}{r}257 \\
34 \\
7\end{array}$ \\
\hline
\end{tabular}

than with the fractionated schedule (100 to $300 \mathrm{mg}, 2-3$ times at 12 hour intervals).

3) The most common side effects with all schedules were: (Table VII)

Diarrhea appeared as the most frequent side effect among the patients of group II - both after the first and the second treatment and only as the third or fourth side-effect among the patients of groups I and III. Since all the patients of group II were given a glass of milk as they ingested the drug, in a population not used to drinking milk, the difference in the incid- ence of diarrhea between the two groups could be traced to this fact.

Vomiting was perhaps the most common among the objective side effects in all groups - since it ranked second in group II, both after the first and second treatment, second in schedule I-A, third in group I-B, and first in group III.

Nausea, a subjective side effect, was very common with variations which may be explained by differences in the psychological behavior of the patients, under the conditions of the treatment of the various

TABLE II

RESULTS OF STOOL EXAMINATIONS IN THE VARIOUS GROUPS

\begin{tabular}{|c|c|c|c|}
\hline \multirow[b]{2}{*}{ GROUP } & \multicolumn{2}{|c|}{ HELMINTH } & \multirow{2}{*}{$\begin{array}{l}\text { Technique } \\
\text { employed }\end{array}$} \\
\hline & Hookworm & A. Iumbricoides & \\
\hline $\begin{array}{l}\text { I } \underset{\mathbf{A}}{\mathbf{A}} \\
\text { (Preliminary trials) }\end{array}$ & $\begin{array}{l}26 \\
12\end{array}$ & $\begin{array}{l}6 \\
3\end{array}$ & $\begin{array}{l}\text { HOFFMAN } \\
\text { et 'al. }\end{array}$ \\
\hline $\begin{array}{l}\text { II } \underset{\mathbf{B}}{\mathbf{A}} \\
\text { (Field trials (rural) }\end{array}$ & 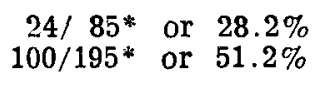 & $\begin{array}{l}42 / 85 \text { or } 49.4 \% \\
98 / 195 \text { or } 50.3 \%\end{array}$ & MIFC \\
\hline $\begin{array}{l}\text { III } \\
\text { (Field trials - semi rúral) }\end{array}$ & $298 / 693^{*}$ or $43.1 \%$ & $341 / 693$ or $49.2 \%$ & MIFC \\
\hline
\end{tabular}

* Positives/examined. 
T A B L E I I I

WORM BURDEN (EGG COUNTS)

\begin{tabular}{|c|c|c|c|c|c|c|c|c|}
\hline \multirow{3}{*}{ GROUPS } & \multirow{2}{*}{\multicolumn{2}{|c|}{$\begin{array}{l}\text { NUMBER OF POSITIVE CASES } \\
\text { HUF'FMANN }{ }^{*}-\text { MIFC ** }\end{array}$}} & \multicolumn{6}{|c|}{ NUMBER OF EGGS (BARBOSA TECHNIQUE } \\
\hline & & & \multicolumn{3}{|c|}{ HOOKWORM } & \multicolumn{3}{|c|}{ A. LUMBRICOIDES } \\
\hline & HCOKWORM & A. LUMBRICOIDES & RANGE & TOTAL & MEAN 3* & RANGE & TOTAL & MEAN \\
\hline , I A* & 22 & 6 & $\begin{array}{l}0-21800 \\
6 \text { cases }\end{array}$ & 22456 & 1020 & $\begin{array}{c}10200- \\
14400\end{array}$ & 24420 & 4070 \\
\hline $\mathbf{B}$ & 16 & 3 & $\begin{array}{l}200 \\
8 \text { cases }\end{array}$ & 2800 & 195 & $2400-$ & 5600 & $\begin{array}{l}1866 \\
\cdot\end{array}$ \\
\hline $\mathrm{II}^{* *}$ & 51 & 39 & $\begin{array}{c}1-420 \\
51 \text { cases }\end{array}$ & 3978 & 78 & $\begin{array}{c}0-1840 \\
39 \text { cases }\end{array}$ & 9648 & 247,2 \\
\hline III $^{* *}$ & 118 & 73 & $\begin{array}{l}0-417 \\
118^{\text {cases }}\end{array}$ & 21423 & 181,5 & $5-3772$ & 53343 & 730 \\
\hline
\end{tabular}

$3^{*}$ Negative cases $(0)$ on egg counts were considered as zero in establishing the mean when eggs were found by the qualitative methods. 
TABLE IV

SUMMARY OF SOME HAEMATOLYGICAL AND BIOCHEMICAL FINDINGS IN 60 PATIENTS FROM 'IHE' RURAL AREA (GRUUP II)

\begin{tabular}{l|c|c|c}
\multicolumn{1}{c|}{ FINDINGS } & RANGE & MEAN & TOTAL \\
\hline RED CELLS (mil/mm3) & $3,0-5,2$ & 4,34 & 260,4 \\
Hb (g\%) & $8,1-14,9$ & 11,8 & 710 \\
HAEMATOCRIT (\%) & $27-50$ & 37,3 & 2240 \\
EOSINOPHILS (\%) & $2-47$ & 16,3 & 980 \\
$\begin{array}{l}\text { TCTAL SERUM PROTEIN } \\
\text { (49 cases) (g\%) }\end{array}$ & $5,8-8,5$ & 6,9 & 340,7 \\
ALB. & $3,2-4,8$ & 4,1 & 205,9 \\
GLOB. & $50-237$ & 2,8 & 4642 \\
$\begin{array}{l}\text { SERUM IRON yg\% } \\
\text { (37 cases) }\end{array}$ & & & \\
\hline
\end{tabular}

TABLE V

SCHEDULES TRIED WITH COMPOUND 16.842 IN THE TREATMENT OF HOOKWCRMS AND AUCARIS LUMBRICOIDES

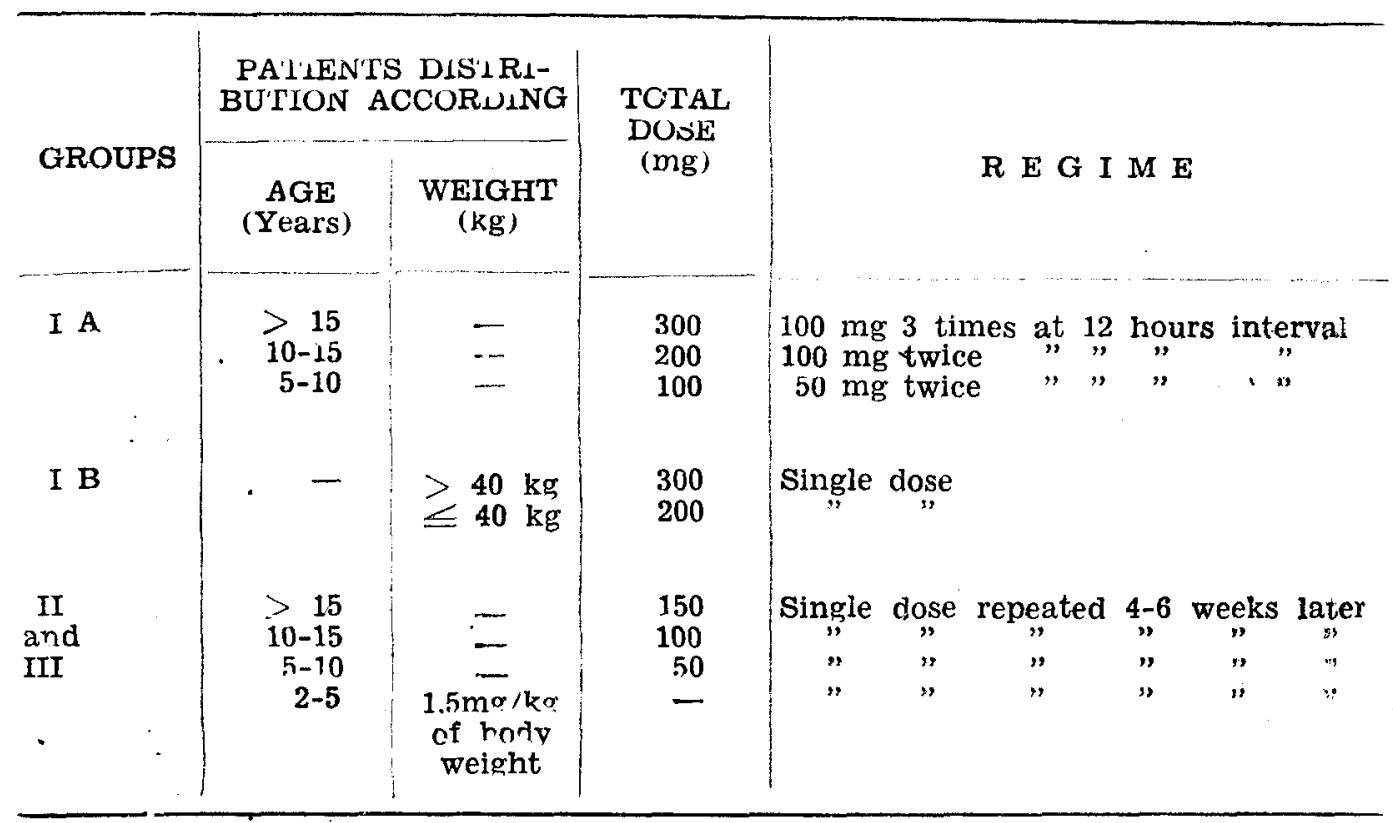


TABLE VI

STOOL EXAMINATIONS SPECIALLY CONSIDERING PCSITIVITY OF HOOKWORM

\begin{tabular}{|c|c|c|c|c|c|}
\hline & \multicolumn{2}{|c|}{$\begin{array}{l}\text { NUMBER AND \% OF } \\
\text { INITIALCY POSITIVE } \\
\text { CASES }\end{array}$} & \multirow{2}{*}{$\begin{array}{c}\text { N.o AND \% OF } \\
\text { HOOKWORM } \\
\text { POSITIVE } \\
\text { CASES ONLY } \\
\text { AFTER THE 1st. } \\
\text { TREATMENT }\end{array}$} & \multirow{2}{*}{$\begin{array}{l}\text { N. AND \% OF } \\
\text { HOOKWORM } \\
\text { POSITIVE } \\
\text { CASES ONLY } \\
\text { AFTER 2nd. } \\
\text { TREATMENT }\end{array}$} & \multirow{2}{*}{$\begin{array}{c}\text { POSITIVE } \\
\text { HOOKWORM } \\
\text { EGG } \\
\text { COUNTS/ } \\
\text { NEGATIVE } \\
\text { MIFC }\end{array}$} \\
\hline & HOOKWORM & A.L. & & & \\
\hline II A & $\begin{array}{c}24 / 85 \\
(28,2 \%)\end{array}$ & $\begin{array}{c}44 / 85 \\
(51,7 \%)\end{array}$ & $\begin{array}{l}6 / 66 \\
(9 \%)\end{array}$ & $\begin{array}{c}4 / 67 \\
(5,9 \%)\end{array}$ & $\begin{array}{c}5 / 30 \\
(16,6 \%)\end{array}$ \\
\hline II $\mathrm{B}$ & $\begin{array}{l}100 / 195 \\
(50 \%)\end{array}$ & $\begin{array}{l}97 / 195 \\
(49,7 \%)\end{array}$ & $\begin{array}{l}17 / 76 \\
(25 \%)\end{array}$ & $\begin{array}{c}9 / 67 \\
(13,4 \%)\end{array}$ & $\begin{array}{l}6 / 66 \\
(9 \%)\end{array}$ \\
\hline III & $298 / 693$ & $\begin{array}{l}341,693 \\
(40,3 \%)\end{array}$ & $0 / 74$ & $\begin{array}{c}12 / 107 \\
(112 \%)\end{array}$ & $\begin{array}{l}2 / 118^{*} \\
(1,6 \%)\end{array}$ \\
\hline
\end{tabular}

* Barhosa Technique was performed almost exclusively in positive cases to MIFC technique.

groups and sub-groups. The mildness of this manifestation could be due, in groups III and specially in II, to the "buffering" effort of milk taken with the drug.

Dizziness, also a subjective symptom, ranked third in the patients of group II and I-A - while in group I-B it ranked first and in group III, second.

Headache was most frequent among the patients who took a high single dose (group I-B) while in all the other groups it was much less frequent.

Another side effect worth discussing was abdominal pain (as a rule, more intense in the epigastric area) which always ranked 4 th or 5 th, with the exception of group I-A, whose patients did not report this side effect.

A comparative analysis of the side-effects in a group of 60 parasited and nonparasited patients showed no difference statistically significant between the two groups.

What must be said about these side effects is that at least dizziness was less frequent with Compound 16.842 , than with tetrachloroethlylene which according to the different authors using the drug, is known to produce that manifestation in mo:s than $50 \%$ of the population treated, at least in Brazil (2).

\section{EFFICACY}

The results of the stool examinations $b y$ the Hoffman et al. technique (on the 8th, 15 and 28-30 days) shown in Table vIr, demonstrate that in 13 out of 22 cases of group I-A, eggs were not present in stools. the parasitological cure rate being $54.5 \%$ If we consider only the results following the last examination (28-30 days) the cure rate increased to $85.4 \%$ (19 cases out of 22 ). In group I-B the total cure rate was $26.6 \%$ according to the last stool examination performed on the 15th day after treatment. According to the results of the first stool examination on the $8^{t} \mathrm{~h}$ day, the cure would be $53.3 \%$.

In group II (Table IX) disappearance of eggs from the stools was observed in 14 out of 42 cases submitted to examination 25-30 days after the first treatment $(33.3 \%)$ while the same fact was observed in 27 out of 59 cases $(45.7 \%)$ subjected to stool examination 25-30 days after the second treatment. (MIFC technique).

Regarding the cases of Sumidouro, Table IX shows that the cure rate was higher 
than that observed in group II, in the small group of patients already analysed for this presentation $64.8 \%$ after the first treatment and $60.5 \%$ after the second course of therapy, according to MIFC technique).

Table VIII also shows the results obtained through the counting technique (Barbosa). The test was positive only in 6 cases of group I-A and in 5 of group I-B. The mean egg counts were 1.020 and 175 eggs respectively. After the last treatment, the egg counts were positive in two and six cases respectively, with mean egg counts of 2 and 80 . The mean egg count dropped from 1020 to $6(99.4 \%)$ after the last treatment, while in group $B$ it dropped from 175 to 80 .

Table IX shows the results of the counting te hnique in groups II and III. Regarding group II, the mean egg count was 78 before treatment. It went up to 248 after the first treatment, with a mean percent reduction of $32.4 \%$, considering that $33.3 \%$ of the cases presented parasitoIngical cure.

In group III, the results of the counting tecilnigue refers to 25 cases before and after the first treatment. The mean egg coun which was $274(0-2140)$ dropped to $98.2(0-390)$ which means a reduction of $64.1 \%$; af $f^{+}$er the second treatment, mean egg count, was 150 .

The results concerning groups II and III refer to followed-up positive hookworm cases, whether or not receiving any of the treatment courses, as the trial was designed for mass treatment. If only the results of followed-up cases which received treatment are considered, parasitological cure in the farms is $36.6 \%$ (11 out, of $\hat{s} 3$ ) after the first course of treatment and $45.5 \%$ (21 out of 46 cases) after the second treatmer.t. In the town of Sumidouro, 24 out of 33 followed-up after the first treatment showed parasitological cure $(72.7 \%)$; this percentage dropped to $55.3 \%(24 / 38)$ after the second treatment. (Table $\mathrm{X}$ ).

The probability of reintection in the group II-A is not to be disregarderl, a fact which seems to be enhar.ced by the lower cure rate observed after the second treatment in relationship to that observed after the first treutment.

Regarding he effect of the drug on Ascuris lumuricoides, (Table XI) the number of cases in group I was too small for conclusions, while in group II and III the results are as follows:

After the first treatment, 21 out of 79 $(26.5 \%)$ showed parasitolog cal cure while only 9 out of $64(14 \%)$ showed cure after the second course of therapy (MIFC technique; .

Considering the reduction of egg counts, the average number of eggs which was 247 before treatment (9-1840) went up to $\$ 1 \mathrm{~S}$ after the first treatment $(0-1190)$ and went up again to $487(0-1953)$ after the second treatment. The mean percent reductions were $27 \%$ and $34.6 \%$ respectively after the first and the second treatment. As far as the effect of Compound 16.842 on Ascaris lumbricoides, tha data of the town of Sumidouro shows results of only a fery cases - with $10.3 \%$ and $22.2 \%$ of negativations after the first and the second treatment respectively. The mean percent reduction was $43.8 \%$ and $47.3 \%$ respectively, in the same situations.

It has to be mentioned that all these patients continued to live in the same unhealth environment where the rate of prevalence of hookworm infection was, as mentioned before, respectively $28.5 \%$ and $51 \%$ with an average of $44.1 \%$, in the two farms and $43 \%$ in the town.

\section{DISCUSSION}

Compound 16.842 appears to be a promising drug against hookworm and with mild action against Ascaris lumbrico:des. Since the drug is, as rule, well tolerated, with the observation that the second dcse is followed by milder side effects than the first one, it is possible to use it either in higher single doses or in courses of the rapy of 2-4 consecutive days. Another important problem to be considered is related to the species or even strains of the parasites, mainly regarding hookworm. Our studies, in order to determine the species of hookworm present in the two rural areas and in the town of sumidouro have not yet been sucessful, but in the two other subgroups the prevalent species was $\mathrm{Ne}$ cator anericanus with a few cases in which both species, Necator and Ancylostoma, duodenale, were associated.

At this stage, it was not possible to compare the value of the drug with other 
antihelmintics which are known to be ef.fective against both hookworm and Ascaris lumbricoides, since previous work on those drugs which showed significant cure rates utilized other techniques for counting eggs. It has been, however, our experience in Brazil that, the Stoll technique (11) always gives higher counts than the Barbcsa technique; nevertheless, the later gives results which are more reproduceable than those of the stoll technique.

\section{COMMENTS ON OTHER DRUGS FOR THE TREATMENT OF HOOKWORM}

A. Trying to compare Compound $\mathbf{1 6 . 8 4 2}$ to tetracholoroethylene, we may see in Tables XII-A and XII-B, that a single dos? of the later gave $92 \%$ of cures in patients living in healthier environments, treated in our out-patient clinics, while using the same schedule it gave $0 \%$ of cures in a group of 20 patients with a higher mean egg count living in a rural and unhealthy environment. (Camillo-Coura et al, unpublished data.)

Regarding tolerance to tetrachloroethylene, we may see in Table XII-C that dizziness and drowsiness were more frequent with tetrachloroethylene than with Compound 16.842. In part, the relatively high incidence of side effects among the patients treated with Compound 16.842 might result from the fact that the patients themselves or their parents were informed in advance to call the local doctor in case of any trouble. Another fact is that the drug was given to several people at the same ocassion and this seems to cause psychological factors which may predispose patients to complain of symptoms which have been described by others and which can be real or imaginary. Another observation, made by the doctor in charge of the trials, is that the intensity of the side effects was in fact m'lder with Compound 16.842 than with tetrachloroethylene, (in the given doses).

\section{B. Bephenium hydroxynaphtoate}

An analysis of the data of Table XIII shows that Bephenium hydroxynaphtoate always gave poor cure rates, except when a $5.0 \mathrm{~g}$ schedule for 3 days, among cases of low density infections with hookworm, was given. $(3,9)$.

\section{Trichlorophenol piperazine (CI-416} Parke Davis)

Table XIV shows that 1-2 day courses of therapy always gave low cure rates. $\mathbf{S}$ de effects were very frequent with longer courses which, nevertheless, gave highcr cure rates. (4).

\section{Thiabendazole}

Thiabendazole ( $25 \mathrm{mg} / \mathrm{kg} / \mathrm{d}$ for 3 days) in 39 cases of low density hookworm infection gave $63 \%$ of cures. Side effects were very mild (Table XV). Analysis on the effect of this drug on other helminths is under way. (unpublished data)

\section{OTHER COMMENTS}

rither facts revealed from this study, mainly from those carried out in the rural areas, are the variations found in the results or stool examinations and egg counts - such as: a) Failure to detect eggs before treatment follnwed by their detect:on only after a first treatment; b) increase in the number of eggs after a first and even a second treatment 24-40 days later; c) Failure to detect eggs in the same sample of stools, by the MIFC technique, followed by their detection by the sedimentation $t$ chnique. It is known that these controversial findings mav occur mainly in cases of light infection. On the other hand, one must consider the posribility of an increase in the number of eggs, due to the evolution of a recent reinfection (previous or pest-treatment) mainly among patients living in highly endemic areas - or to normal fluctuations on the oviposition. Th's last fact may either favor any given drug or hamper the results of therapy.

The explanatiol. for the discrepancies observed in soma of the above results refficacy) are being explnred and will perhaps be found onl'y after mure accurate studies are performed. New ricls are forcast, examining at least thrue difieront samples of stuols and wy having the patient submitter to more friquent post treaiment stool examinations using the mosi relable techniques. The trials should be couducted under different conditions i.e., while one group would continue to live in the same previous sanitary conditions. another group would have these environmental 
T A B L E V I I

SIDE EFFECTS OBSERVED AMONG THE PATIENTS OF THE 3 GROUPS TREATED WITH CCMPOUND 16.842

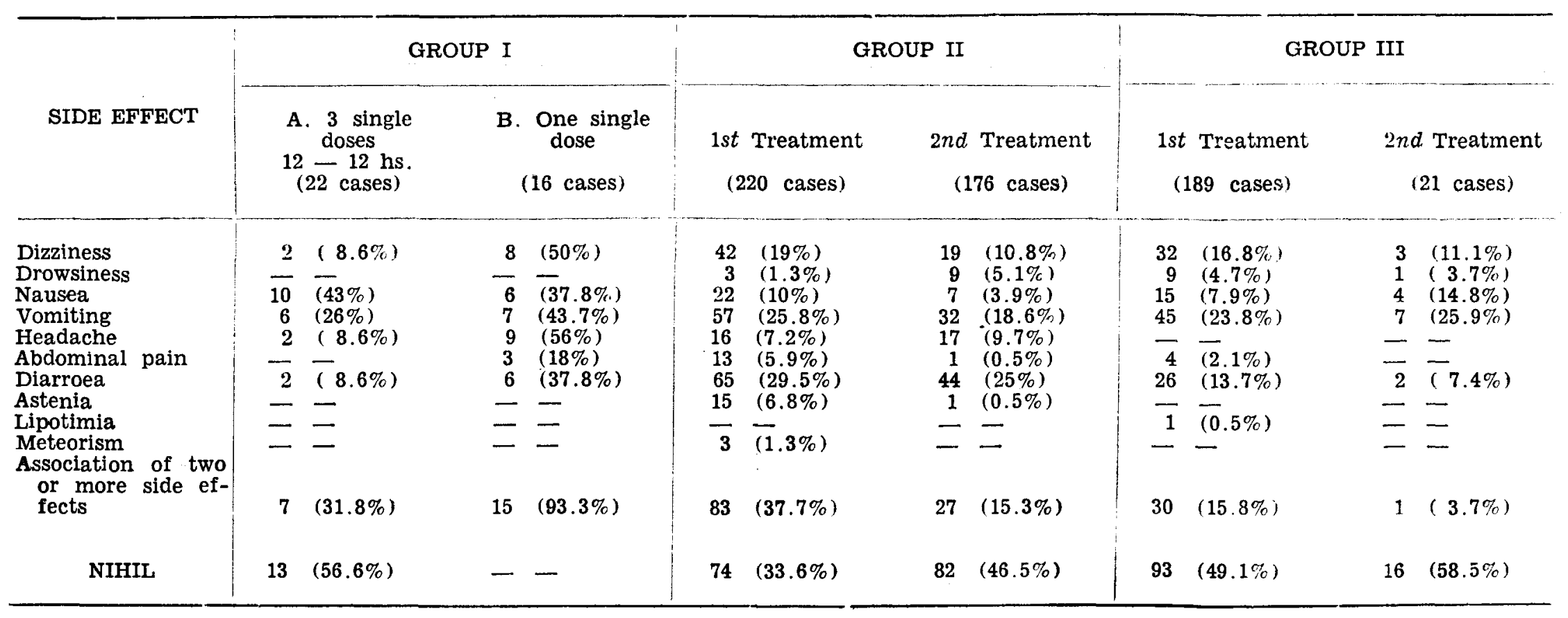


T A B L E V I I I

EFFECT OF COMPOUND 16.842 UPON HOOKWORM INFECTION (GRCUP I)

\begin{tabular}{|c|c|c|c|c|c|c|c|c|c|c|c|c|c|}
\hline \multirow[b]{2}{*}{$\underset{\text { I }}{\text { GROUP }}$} & \multicolumn{3}{|c|}{ BEFORE TREATMENT } & \multicolumn{3}{|c|}{$\begin{array}{l}\text { FOLLCWING FIRST } \\
\text { CONTROL (8th DAY) }\end{array}$} & \multicolumn{3}{|c|}{$\begin{array}{l}\text { FOLLCWING SECOND } \\
\text { CONTROL (15th DAY) }\end{array}$} & \multicolumn{3}{|c|}{$\begin{array}{l}\text { FOLLOWING THIRD } \\
\text { CONTROL }\end{array}$} & \multirow{2}{*}{ 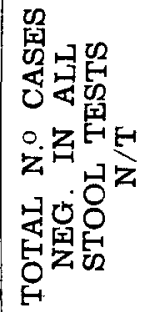 } \\
\hline & $\begin{array}{c}\text { N. O OF } \\
\text { CASES } \\
\text { TREATED }\end{array}$ & $\begin{array}{l}\text { TOTAL } \\
\text { N.O OF } \\
\text { EGGS* }\end{array}$ & $\begin{array}{l}\text { MFAN } \\
\text { EGG } \\
\text { COUNTS }\end{array}$ & $\begin{array}{c}\text { N. OF } \\
\text { CASES } \\
\text { OBSERV- } \\
\text { ED N/T ** }\end{array}$ & $\begin{array}{l}\text { TOTAL } \\
\text { N.O OF } \\
\text { EGGS }\end{array}$ & $\begin{array}{c}\text { MEAN } \\
\text { EGG } \\
\text { COUNTS }\end{array}$ & $\begin{array}{c}\text { N.O OF } \\
\text { CASES } \\
\text { OBSERV- } \\
\text { ED N/T * }\end{array}$ & $\begin{array}{c}\text { TCTAL } \\
\text { N.O OF } \\
\text { EGGS }\end{array}$ & $\begin{array}{c}\text { MEAN } \\
\text { EGG } \\
\text { COUNTS }\end{array}$ & $\begin{array}{c}\text { N.O OF } \\
\text { CASES } \\
\text { OBSERV- } \\
\text { ED N } / T * *\end{array}$ & $\begin{array}{c}\text { TOTAL } \\
\text { N.O OF } \\
\text { FGGS }\end{array}$ & $\begin{array}{c}\text { MEAN } \\
\text { EGG } \\
\text { COUNTS }\end{array}$ & \\
\hline A & 22 & $\begin{array}{l}22.456 \\
(6 \text { cases })\end{array}$ & $\begin{array}{c}1.020 \\
(0-21.800)\end{array}$ & $\begin{array}{l}13 / 21 \\
(51 \%)\end{array}$ & 2482 & $\begin{array}{c}310 \\
(0-1800)\end{array}$ & $\begin{array}{c}10 / 21 \\
(76.2 \%)\end{array}$ & 600 & $\begin{array}{c}120 \\
(0-600)\end{array}$ & $\begin{array}{c}19 / 22 \\
(85.4 \%)\end{array}$ & 6 & $\begin{array}{c}2 \\
(0-6)\end{array}$ & $\begin{array}{c}13 / 22 \\
(54.5 \%)\end{array}$ \\
\hline $\mathrm{B}$ & 16 & $\begin{array}{c}2.800 \\
(5 \text { cases })\end{array}$ & $\begin{array}{c}175 \\
(0-800)\end{array}$ & $\begin{array}{c}9 / 16 \\
(56.2 \%)\end{array}$ & 1180 & $\begin{array}{c}168 \\
(0-1000)\end{array}$ & $\begin{array}{c}8 / 15 \\
(53.3 \%)\end{array}$ & 2200 & $\begin{array}{c}80 \\
(0-1200)\end{array}$ & & & & $\begin{array}{c}6 / 16 \\
(26.6 \%)\end{array}$ \\
\hline
\end{tabular}

* Only 6 out of 22 cases found positive for Ancylostomidae by the Hoffman Technique were positive by the sedimentaition count method (Barbosa).

** Negative/treated and followed up. 
T A B L E IX

EFFECT OF COMPOŨND 16.842 ON HCOKWORM INFECTION (GROUPS II AND III))

\begin{tabular}{|c|c|c|c|c|c|c|c|c|c|c|c|}
\hline \multirow{3}{*}{ GROUP } & \multirow{3}{*}{$\begin{array}{c}\text { POSITIVE } \\
\text { CASES }\end{array}$} & \multirow{2}{*}{\multicolumn{2}{|c|}{ BEFORE TREAT. }} & \multicolumn{8}{|c|}{ EGG COUNTING (BARBOSA TECHNIQUE) } \\
\hline & & & & \multicolumn{4}{|c|}{ AFTER 1st. TREATMENT } & \multicolumn{4}{|c|}{ AFTER 2nd. TRATMENT } \\
\hline & & $\begin{array}{c}\text { TOTAL } \\
\text { NUMBER }\end{array}$ & MEAN & $\begin{array}{l}\text { TOTAL } \\
\text { NUMBER }\end{array}$ & MEAN & $\begin{array}{l}\text { MEAN \% OF } \\
\text { REDUCTICN }\end{array}$ & $\mathrm{C} / \mathrm{T} *$ & $\begin{array}{l}\text { TOTAL } \\
\text { NUMBER }\end{array}$ & MEAN & $\begin{array}{l}\text { MEAN \% OF } \\
\text { REDUCTICN }\end{array}$ & $\mathrm{C} / \mathrm{T} *$ \\
\hline$\stackrel{\text { II }}{+} \mathbf{B}$ & $\begin{array}{ll} & 124 \\
(114 & \text { treated })\end{array}$ & $\begin{array}{c}3978 \\
(67 \text { cases })\end{array}$ & $\begin{array}{c}78 \\
(0-420)\end{array}$ & $\left(49^{12771}\right.$ cases $)$ & $\begin{array}{c}248 \\
(0-1127)\end{array}$ & $32.4 \%$ & $\begin{array}{c}14 / 42 \\
(33.3 \%)\end{array}$ & $\begin{array}{c}4029 \\
\text { (48 cases) }\end{array}$ & $\begin{array}{c}83.9 \\
(0-380)\end{array}$ & $69.6 \%$ & $\begin{array}{c}27 / 59 \\
(45,7 \%)\end{array}$ \\
\hline III & (134 $\begin{array}{l}268 \\
\text { treated) }\end{array}$ & $\begin{array}{c}6871 \\
(25 \text { cases })\end{array}$ & $\begin{array}{c}274 \\
(0-2140)\end{array}$ & $\begin{array}{c}2456 \\
(25 \text { cases })\end{array}$ & $\begin{array}{c}98,2 \\
(0-390)\end{array}$ & $57.5 \%$ & $\begin{array}{c}2.4 / 37 \\
(64.8 \%)\end{array}$ & $(24 \stackrel{4613}{\text { cases })}$ & $\begin{array}{c}150 \\
(0-1633)\end{array}$ & $57.6 \%$ & $\begin{array}{c}26 / 43 \\
(60.5 \%)\end{array}$ \\
\hline
\end{tabular}

$\mathrm{C} / \mathrm{T}-$ cured/treated 
T A B L E X

COMPARISON OF RESULTS OF THERAPY WITH COMPOUND 16.842 ON HOCKWORM INFECTION (GROUPS II AND III), IN FOLIOWEDUP PATIENTS*

\begin{tabular}{|c|c|c|c|c|c|c|c|c|c|}
\hline \multirow[b]{2}{*}{ GROUP } & \multirow{2}{*}{$\begin{array}{c}\text { NUMBER OF } \\
\text { CASES } \\
\text { FOLLOWED } \\
\text { UP }\end{array}$} & \multicolumn{4}{|c|}{$\begin{array}{c}\text { TOTAL CURES (TREATED AN NOT TREATED } \\
\text { FOLLOWED-UP) }\end{array}$} & \multicolumn{4}{|c|}{ CURES (TREATED AND FOLLOWED-UP) } \\
\hline & & AFTER & 1st. COURSE & AFTER & 2nd. COURSE & AFTER & 1st. COURSE & AFTER 2nd. & COURSE \\
\hline & & $\mathrm{C} / \mathrm{T}^{* *}$ & $\%$ & $\mathrm{C} / \mathrm{T}$ & $\%$ & $\mathrm{C} / \mathrm{T}$ & $\%$ & $\mathrm{C} / \mathrm{T}$ & $\%$ \\
\hline II A & $\begin{array}{l}\text { 1st. course: } 16 \\
\text { 2nd. course: } 23\end{array}$ & $\underline{5} / 16$ & 31.2 & $8 / 23$ & 34.7 & $5 / 13$ & 38.4 & $4 / 16$ & 25.3 \\
\hline B & $\begin{array}{l}\text { 1st. course: } 26 \\
\text { 2nd. course: } 36\end{array}$ & $9 / 26$ & 34.3 & $19 ; 36$ & 52.8 & $9 ; 25$ & 34.3 & $17 / 30$ & 56.6 \\
\hline III & $\begin{array}{l}\text { 1st. course: } 37 \\
\text { 2nd. course: } 43\end{array}$ & $24 / 37$ & 64.8 & $26 / 43$ & 60.5 & $24 / 33$ & 72.7 & $21 / 38$ & 55.3 \\
\hline
\end{tabular}

* according to Mifc Technique

* cured/treated 
T A B L E X I

EFFECT OF COMPOUND 16.842 ON ASCARIS LUMBRICOIDES

\begin{tabular}{|c|c|c|c|c|c|c|c|c|c|c|c|}
\hline \multirow{2}{*}{ GROUP } & \multicolumn{3}{|c|}{$\begin{array}{c}\text { NUMBER OF EGGS BEFORE } \\
\text { TREATMENT }\end{array}$} & \multicolumn{4}{|c|}{ EXAM, AFTER 1st, TREATMENT } & \multicolumn{4}{|c|}{ AFTER 2nd. TREATMENT } \\
\hline & TOTAL & RANGE & MEAN & $\begin{array}{l}\text { TOTAL } \\
\text { NUMBER }\end{array}$ & MEAN & $\begin{array}{l}\text { MEAN \% } \\
\text { REDUCTICN }\end{array}$ & $\mathrm{C} / \mathrm{T}^{*}$ & TOTAL & MEAN & $\begin{array}{l}\text { MEAN \% } \\
\text { REDUCTION }\end{array}$ & $\mathrm{C} / \mathrm{T}$ \\
\hline I A & $\begin{array}{l}22420 \\
(6 \text { cases })\end{array}$ & $0-14400$ & 4070 & 600 & $\begin{array}{c}100 \\
(0-600)\end{array}$ & $83.3 \%$ & $\begin{array}{c}2 / 6 \\
(33.3 \%)\end{array}$ & - & - & - & - \\
\hline $\mathbf{B}$ & $\begin{array}{l}5600 \\
(3 \text { cases })\end{array}$ & $0-3200$ & 2800 & 10300 & $\begin{array}{c}3600 \\
(600-9000)\end{array}$ & $54 \%$ & $0 / 3$ & & & & \\
\hline II & $\begin{array}{c}9648 \\
\text { (39 cases) }\end{array}$ & $0-1840$ & 247,2 & $\begin{array}{l}9827 \\
\text { (31 cases) }\end{array}$ & $\begin{array}{c}319 \\
(0-1190)\end{array}$ & $27 \%$ & $\begin{array}{c}21 / 79 \\
(26.5 \%)\end{array}$ & $\begin{array}{c}19975 \\
(41 \text { cases })\end{array}$ & $\begin{array}{c}487 \\
(0-1953)\end{array}$ & $34.6 \%$ & $\begin{array}{c}9 / 64 \\
(14 \%)\end{array}$ \\
\hline III & $\begin{array}{c}53343 \\
(73 \text { cases) }\end{array}$ & $5-3772$ & 730 & $\begin{array}{c}7432 \\
\text { (19 cases) }\end{array}$ & $\begin{array}{c}391 \\
(0-1574)\end{array}$ & $43,8 \%$ & $\begin{array}{c}2 / 19 \\
(10.5 \%)\end{array}$ & $\begin{array}{c}21766 \\
\text { (19 cases) }\end{array}$ & $\underset{(-8667)}{1145}$ & $47.3 \%$ & $\begin{array}{c}3 / 18 \\
(22.2 \%)\end{array}$ \\
\hline
\end{tabular}

- Cured/Treated. 
T A B L E X I I I

BEPHENIUM HYDROXYNADHTOATE IN THE TREATMENT OF CUT-PATIENTS WITH HOOKWORM INFECTION

\begin{tabular}{|c|c|c|c|c|c|c|c|c|c|c|}
\hline \multirow{3}{*}{$\begin{array}{c}\text { PRESENTATION } \\
\text { OF } \\
\text { DRUG }\end{array}$} & \multicolumn{2}{|c|}{ SCHEDULE } & \multicolumn{4}{|c|}{ LOW INFECTION DENSITY } & \multicolumn{4}{|c|}{ HIGH INFECTION DENSITY } \\
\hline & \multirow[t]{2}{*}{$\begin{array}{c}\text { DAILY } \\
\text { DOSE }\end{array}$} & \multirow[t]{2}{*}{$\begin{array}{l}\text { DAYS } \\
\text { OF } \\
\text { TRFAT- } \\
\text { MENT }\end{array}$} & \multicolumn{2}{|c|}{$\begin{array}{c}\text { STOOL EXAM. BEF- } \\
\text { ORE TREATMENT } \\
\text { NUMBER OF EGGS/ML } \\
\text { STOOL (STOLL } \\
\text { TECHNIQUE) }\end{array}$} & \multirow[t]{2}{*}{$\begin{array}{c}\text { PERCENTAGE } \\
\text { OF EGG } \\
\text { REDUCTION }\end{array}$} & \multirow[t]{2}{*}{$\mathbf{N} / \mathbf{T}^{*}$} & \multicolumn{2}{|c|}{$\begin{array}{c}\text { STOOL EXAM. BEF- } \\
\text { ORE TREATMENT } \\
\text { NUMBER OF EGGS/ML } \\
\text { STOOL (STOLL } \\
\text { TECHNIQUE) }\end{array}$} & \multirow[t]{2}{*}{$\begin{array}{c}\text { PERCENTAGE } \\
\text { OF EGG } \\
\text { REDUCTION }\end{array}$} & \multirow[t]{2}{*}{$\mathrm{N} / \mathrm{T}^{*}$} \\
\hline & & & RANGE & MEAN & & & RANGE & MEAN & & \\
\hline \multirow{4}{*}{ MICROPELLETS } & $2.5 \mathrm{~g}$ & 1 & $100-2000$ & 773 & 59 & $11 / 29$ & $7800-13800$ & 10800 & 85 & $0 / 2$ \\
\hline & $2.5 \mathrm{~g}$ & 2 & $200-1080$ & 1080 & 60 & $8 / 31$ & $0-6400$ & 6400 & 87.5 & $0 / 1$ \\
\hline & $2.5 \mathrm{~g}$ & 3 & $100-2000$ & 800 & 74 & $7 / 11$ & $3000 \sim 18000$ & 8000 & 44 & $1 / 3$ \\
\hline & $2.5 \mathrm{~g}$ & 1 & $100-2500$ & 1038 & 56 & $8 / 29$ & $3000-44300$ & 11544 & 55 & $0 / 11$ \\
\hline \multirow[t]{2}{*}{ GRANULES } & $2.5 \mathrm{~g}$ & 3 & $400-1200$ & 925 & 77 & $1 / 4$ & $4000-5600$ & 4800 & 85 & $0 / 2$ \\
\hline & $5.0 \mathrm{~g}$ & 3 & $100-900$ & 514 & 85 & $6 / 7$ & - & - & - & - \\
\hline
\end{tabular}

* Negative/treated 
T A B L $E$ X IV

TRICHLOROPHENOL PIPERAZINF, (CI-416, IN THE TREATMENT OF OUT-PATIENTS WITH HOOKWORM INFECTION

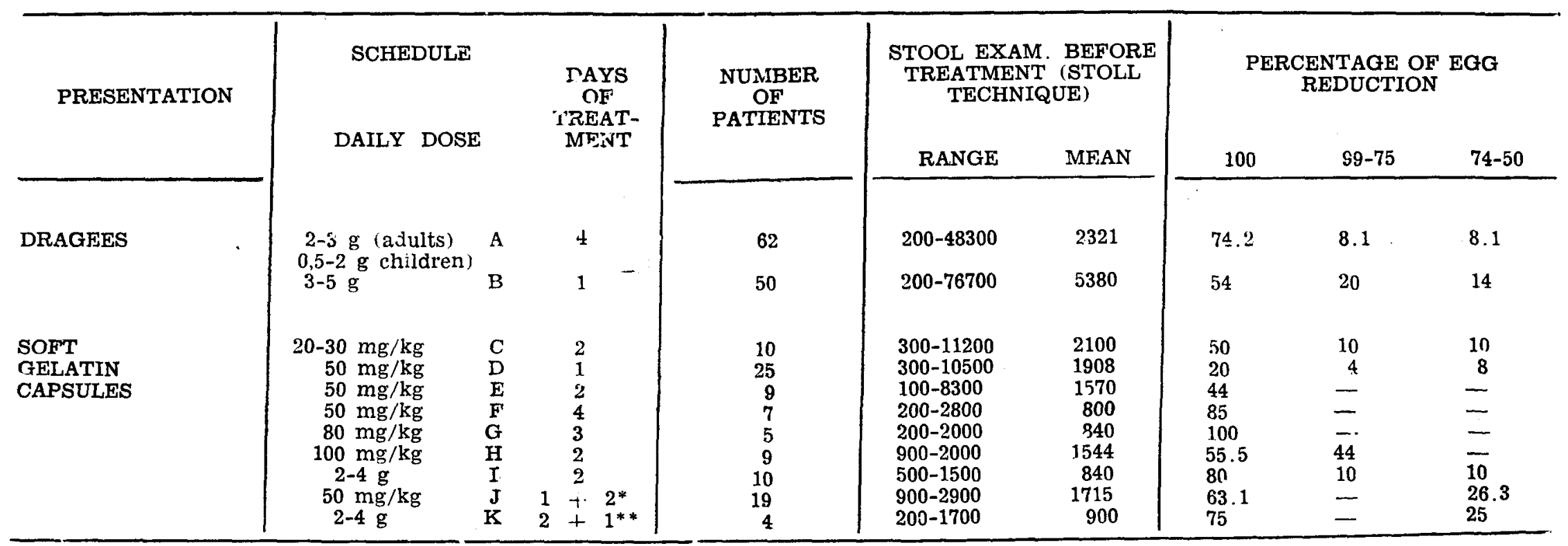

* Seven days after

* Ten days after 
conditions changed, wearing of shoes included, besides health education.

Finally it must be pointed out that, since this trial deals almost ex:lusively with Necator americanus, the relatively low cure rates obtained may be due to the fact that that species of hookworm is more resistant to therapy than Ancylostoma duodenale a fact mentioned by Hsieh et al. (8), among patients treated with Bephenium.

\section{ACKNOWLEDGMENTS}

The a thors wish to express their apprecia"ion to "Hoechst do Brasil, Quimica e Farmaceutica, S.A.", in the person of Dr. Wilhelm Fill, for the supply of Compound 16.842 and material support for the trial. Considerable assistan ze in this study was obtained from the staff of the Instituto Nacional de Endemias Rurais, especially from Miss Genoveva Sampaio, health educator of the Sumidouro project, and from Dra. Adelina Velho Soli.

\section{$S U M A R I O$}

Os autores ensaiam um nôvo antihelmintico, Composto 16.842, em 3 grupos ¿le pacientes de modo a testar sua eficácia, tolerância $e$ a possibilidade de seu cmprêgo em campanhas de massa contra ancilostomiase. O primeiro grupo, em que se empregou a droga em ensaio preliminar, consistiu de um grupo de 38 jacientes de ambulatório do Serviço e de um orfanato no Estado da Guanahara. No grupo II administrou-se o medicamento a tôda a população de duas razendas no municipio de Sumidouro e no grupo III inciuiu-se grande parte da jopulacão da pequena cidade de sumidouro.

$A$ tolerância foi satisfatória, principalmente nos pacientes que receberam 2 doses de 50 a $150 \mathrm{mg}$ com intervalos de 4 a 6 semanas e os resultados obtidos sugerem que 2 a 4 cursos de tratamento num menor periodo de tempo são ideais para tratamento em massa.

A cura parasitológica variou de $26,6 \%$ a $76,2 \%$ nos vários grupos, com grande ariação também nos percentuais de redução média do número de ovos de anrilostomideos nas fezes.

Observou-se efeito contra Ascaris lumbricoides, com indices de cura de 13,5 a $35.7 \%$ nos vários grupos.

Concluem os autores que o Composto 16.842 tem seu lugar no tratamento r'a infecçāo por ancilostomídeos e que sâo necessários maiores estudos para determinar os esquemas terapêticos mais eficientes.

\section{REFERENCES}

BARBOSA, F. S., - Morididade na Esquistossomose. (A thesis) 176, pp. Recife, 1965.

$\therefore$ CAMILLO-COURA, L. ET AL - Ensaios sôbre a terapêutica antihelmíntica com sais de piperazina, tetrachloretileno e hidroxinoftoato de befenio. Paper presented to the IX Brazilian Congress of Medicine, Rio de Janeiro, July, 1962.

CAMILLO-COURA, L. ET AL - $\mathrm{O}$ hidroxinaftoato de befenio no tratamento de algumas parasitoses intestinais humanas. O Hospital, 69: .... 981-989, 1966.

4 CAMILLO-COURA, L. ET AL - Therapeutical trials with a new antihelmintic-trichlorophenol piperazine (CI 416) on hookworm, Ascaris lumbricoides, and Trichuris trichiura. J. Bras. Med. Irop., I, I, 57-64, 1967.
5. COU'INHO, J.O. - Nota sôbre modificações do MIFC na conservação de fezes para pesquisa de cistos e protozoários. Arc. Fac. Hig. e Saúde Publ. Univ. S. Paulo, 10 (1-2), 1956.

6. FERREIRA, L. F. - O exame parasitológico das fezes - estudo comparativo de principais técnicas. O Hospital, 70: 347-368, 1966.

7. HOFFMANN, W. A. ET AL - The sedimentation-concentration method in Schistosomiasis mansoni: Puerto Rico, J.P. Heaith, Trop. Medicine, 9: 283-291, 1934.

8. HSIEH-CHEN HSIEN ET AL - The treatment of hookworms, Ascaris lumbricoides, and Trichuris infections with Bephenium hydroxynaphtoate. J. Trop. Med. Hyg. 9: 496-499, 1960.

9 . RCDRIGUES DA SILVA, J. ET AL O hidroxinaftoato de Befenio no tratamento da ancilostomiase, ascaridiase e tricuriase. J. Bras. Med. 6: .. 270-288, 1962. 
10. SAPERO, J.J . \& LAWLESS, D.K. The "MIF" stain preservation technigue for the identification of intestinal protozoa. Am. J. Trop. Med.
Hyg. 2, 4: 613-619, 1953

11. STOLL, N.R. - An effective method of counting hookworm eggs in feces. Am, J. Hyg. 3: 59-70, 923 . 